DOI: 10.19195/2300-7729.35.10

JACEK WILLECKI

Biblioteka Politechniki Poznańskiej

\title{
Projekty biblioteczne uczelni publicznych finansowane ze środków krajowych i europejskich znajdujących się w dyspozycji instytucji szczebla krajowego i regionalnego w Polsce
}

Biblioteki uczelni publicznych to centra wiedzy i nauki oferujące dostęp do informacji w postaci papierowej, cyfrowej i multimedialnej. Zmieniające się dynamicznie otoczenie gospodarczo-społeczne wpływa na preferencje użytkowników zbiorów naukowych bibliotek. Czytelnicy są zainteresowani dostępem do najnowszej wiedzy, który nie powinien być ograniczony godzinami pracy bibliotek akademickich. Odpowiedzią bibliotek na takie zapotrzebowanie jest możliwość korzystania z zasobów naukowych w formie elektronicznej, dostępnej bez ograniczeń dla wszystkich użytkowników w przypadku zasobów otwartych, lub dla uprawnionych uży tkowników w przypadku zasobów charakteryzujących się ograniczeniami w dostępie, wynikającymi z postanowień określonej licencji. Rozwój cyfrowych zasobów bibliotek wymaga dobrej polityki uczelnianej w zakresie gromadzenia dorobku naukowego swoich pracowników, dobrej infrastruktury informatycznej, odpowiedniego poziomu e-cyfryzacji uczelni, sprawnego zarządzania repozytoriami naukowymi, współpracy konsorcjalnej gwarantującej dostęp do najlepszych baz czasopism i książek, ale przede wszystkim odpowiednich środków na przedstawione działania. Mogą one pochodzić z budżetów uczelni lub dotacji bezzwrotnych przyznawanych przez instytucje szczebla krajowego i regionalnego funkcjonujących w Polsce. Biblioteki mają dzięki temu możliwość wyboru źródła finansowania swoich działań prorozwojowych. Należy jednak pamiętać, że budżety uczelni nie zawsze w pełni odpowiadają bieżącym potrzebom ich jednostek, a środki pozabudżetowe, dotacyjne są przyznawane w trybie konkursowym. Jednak najważniejszym argumentem przemawiającym za środkami w postaci dotacji jest ich dostępność w budżetach instytucji krajowych i regio- 
nalnych w budżecie krajowym w postaci środków na naukę, a także w budżetach środków europejskich w ramach perspektywy finansowej na lata 2014-2020. W celu przybliżenia potencjalnych możliwości finansowania projektów bibliotecznych przez uczelnie publiczne w artykule dokonano przeglądu najważniejszych źródeł ich finansowania w zależności od poziomu dystrybucji środków. Zakresem analizy zostały objęte dwie formy wsparcia oferowane bibliotekom przez Ministerstwo Nauki i Szkolnictwa Wyższego, reprezentujące poziom krajowy dystrybucji dotacji. Pierwsza forma to dofinansowanie ze środków krajowych bibliotecznej działalności upowszechniającej naukę, a druga to zapewnienie dostępu do informacji naukowej. Analizie poddano również formy wsparcia pochodzące z poziomu krajowego, finansowane ze środków europejskich, pozostających w dyspozycji Centrum Projektów Polska Cyfrowa, Narodowego Centrum Badań i Rozwoju i Ministerstwa Kultury i Dziedzictwa Narodowego. Jednocześnie analizie poddano wsparcie oferowane ze środków europejskich, dystrybuowane z poziomu regionalnego przez Urzędy Marszałkowskie w ramach Regionalnych Programów Operacyjnych. Ponadto analiza uwzględnia typy inwestycji zarówno w kapitał ludzki, jak i w infrastrukturę techniczną kwalifikujących się do finansowania ze środków krajowych oraz europejskich, co pozwoli zainteresowanym podmiotom na uzyskanie syntetycznej informacji służącej pozyskaniu wybranych dotacji, przy uwzględnieniu skali projektu i doświadczenia w realizacji podobnych przedsięwzięć.

Ministerstwo Nauki i Szkolnictwa Wyższego za pośrednictwem Departamentu Nauki odpowiada za organizację naboru, oceny i rozliczania wniosków dotyczących finansowania bibliotecznej działalności upowszechniającej naukę. Głównym celem działalności ministerialnej w tym zakresie jest wsparcie polskiej nauki przez działalność bibliotek w obszarze upowszechniania, promocji, popularyzacji wyników działalności badawczej, rozwojowej, innowacyjnej i wynalazczej w skali krajowej i międzynarodowej. Beneficjentami wsparcia mogą zostać uczelnie wyższe mające w swojej strukturze biblioteki naukowe będące samodzielnymi jednostkami, a z możliwości wsparcia są wyłączone biblioteki wydziałowe i międzyuczelniane ${ }^{1}$. Typy inwestycji podlegających wsparciu to utrzymanie unikatowych w skali kraju zasobów bibliotecznych o istotnym znaczeniu dla nauki lub jej dziedzictwa, opracowywanie naukowych zasobów bibliotecznych i udostępnianie zasobów bibliotecznych $\mathrm{w}$ formie elektronicznej, a przy ocenie złożonych wniosków uwzględnia się kryteria znaczenia zbiorów dla nauki lub jej dziedzictwa, znaczenie zaplanowanych do opracowania zbiorów dla upowszechniania nauki, współpracy krajowej i międzynarodowej w zakresie utrzymania, opracowania i udostępniania zbiorów w postaci elektronicznej, form, metod i zakresu elektronicznego udostępniania zbiorów. Jednocześnie donator dopuszcza możliwość

${ }^{1}$ Ministerstwo Nauki i Szkolnictwa Wyższego, Ustawa o zasadach finansowania nauki z dnia 30 kwietnia 2010 r., Dz.U. 2015, poz. 249, 1268. 
finansowania bibliotecznej działalności upowszechniającej naukę przez montaż finansowy środków ministerialnych i własnych beneficjenta, który może w budżecie przedsięwzięcia wyodrębnić koszty pośrednie ${ }^{2}$. Ministerstwo Nauki i Szkolnictwa Wyższego przyznaje także dofinansowanie i rozlicza przedsięwzięcia w ramach działalności statutowej, związane z zapewnieniem dostępu do informacji naukowej w bibliotekach akademickich. Głównym celem tego przedsięwzięcia jest wsparcie uczelni w zakresie zwiększenia dostępu do elektronicznych naukowych baz danych i publikacji naukowych poprzez finansowanie zakupu systemów udostępniających informacje o wynikach badań naukowych, publikacjach i monografiach, w tym do Wirtualnej Biblioteki Nauki. Beneficjentami wsparcia mogą zostać uczelnie wyższe, które we wniosku aplikacyjnym dokonają rzetelnej charakterystyki liczby jednostek organizacyjnych uczelni i pracowników naukowych w nich zatrudnionych, merytorycznej zawartości baz elektronicznych zgłaszanych do dofinansowania, zasięgu krajowego lub międzynarodowego udostępnianej informacji naukowej, okresu, w jakim uczelnia korzystała z dostępu do informacji naukowej przed złożeniem wniosku, oraz analizy zawartości merytorycznej baz elektronicznych planowanych do wsparcia, w porównaniu do innych zasobów naukowych w dostępie on-line finansowanych aktualnie przez beneficjenta ze środków budżetowych. Typy działań podlegających wsparciu to umożliwienie dostępu do elektronicznych baz danych zawierających informację naukową oraz do Wirtualnej Biblioteki Nauki, a donator zakłada częściowe finansowanie zakupu takiego dostępu ${ }^{3}$.

Centrum Projektów Polska Cyfrowa jako Instytucja Pośrednicząca Ministerstwa Rozwoju odpowiada za organizację naborów wniosków konkursowych, ich ocenę oraz rozliczanie w zakresie projektów finansowanych z Programu Operacyjnego Polska Cyfrowa. W ramach osi priorytetowej II e-administracja i otwarty urząd, działania 2.3 cyfrowa dostępność i użyteczność informacji sektora publicznego, poddziałania 2.3.1 cyfrowe udostępnienie informacji sektora publicznego ze źródeł administracyjnych i zasobów nauki, finansowane będą m.in. inwestycje służące przede wszystkim zwiększeniu dostępności i poprawy jakości informacji sektora publicznego, związane ze zwiększeniem możliwości ich ponownego wykorzystania. Głównym celem działań projektowych w zakresie zasobów nauki, podejmowanych w ramach wyżej wymienionej osi, działania i poddziałania, jest

${ }^{2}$ Ministerstwo Nauki i Szkolnictwa Wyższego, rozporządzenie Ministra Nauki i Szkolnictwa Wyższego z dnia 27 października 2015 r. w sprawie kryteriów i trybu przyznawania oraz rozliczania środków finansowych na działalność upowszechniającą naukę, Dz.U. 2015, poz. 1862.

${ }^{3}$ Ministerstwo Nauki i Szkolnictwa Wyższego, rozporządzenie Ministra Nauki i Szkolnictwa Wyższego z dnia 11 września 2015 r. w sprawie szczegółowych kryteriów i trybu przyznawania oraz rozliczania środków finansowych na utrzymanie specjalnego urządzenia badawczego, specjalnego urządzenia badawczego z zakresu infrastruktury informatycznej nauki, zapewnienia dostępu do informacji naukowej, w tym do Wirtualnej Biblioteki Nauki, oraz na pokrycie kosztów restrukturyzacji jednostek naukowych, Dz.U. 2015, poz. 1462. 
udostępnianie zasobów naukowych w sposób otwarty, w formatach dostosowanych do przetwarzania maszynowego, $w$ formie elektronicznej i opatrzonej metadanymi, co do zasady nieodpłatnie oraz bez ograniczeń przy ich ponownym, wielokrotnym wykorzystywaniu. Beneficjentami wsparcia mogą zostać uczelnie wyższe, w tym zawodowe szkoły wyższe sektora publicznego, które mogą uzyskać dofinansowanie do $100 \%$ kosztów kwalifikowalnych projektu ${ }^{4}$. Typy inwestycji podlegających wsparciu unijnemu to budowa interoperacyjnych, naukowych repozytoriów cyfrowych o szerokim zasięgu oddziaływania, zorientowanych na użytkownika. Wydatki kwalifikowalne związane $\mathrm{z}$ tego typu przedsięwzięciem obejmują m.in. zakup oprogramowania, wyposażenia informatycznego, sprzętu do digitalizacji, usług zewnętrznych, informatycznych oraz robót budowlanych ${ }^{5}$.

Narodowe Centrum Badań i Rozwoju jako Instytucja Pośrednicząca Ministerstwa Rozwoju odpowiada za nabór, ocenę i rozliczanie wniosków projektowych finansowanych z Programu Operacyjnego Wiedza Edukacja Rozwój. W ramach osi priorytetowej III szkolnictwo wyższe dla gospodarki i rozwoju, działania 3.4 zarządzanie $\mathrm{w}$ instytucjach szkolnictwa wyższego, będą finansowane projekty związane $\mathrm{z}$ wprowadzaniem zmian organizacyjnych i podniesieniem jakości kadr pracowników szkolnictwa wyższego. Głównym celem działań podejmowanych w ramach wymienionej osi i działania jest wdrożenie zmian w zakresie zarządzania procesem kształcenia. Typy inwestycji podlegających dofinansowaniu unijnemu, które mogą być realizowane bezpośrednio lub pośrednio przez biblioteki akademickie, obejmują m.in. wsparcie innowacyjnego procesu dydaktycznego, procesów konsolidacji uczelni, umiejętności informatycznych, posługiwania się profesjonalnymi bazami danych w procesie kształcenia, zarządzania informacją i pozyskiwania zewnętrznych środków finansowych, w tym z programu Horyzont 2020. Beneficjentami wsparcia mogą zostać uczelnie wyższe, w tym zawodowe szkoły wyższe sektora publicznego, które mogą uzyskać dofinansowanie do 97\% kosztów kwalifikowalnych projektu ${ }^{6}$.

Ministerstwo Kultury i Dziedzictwa Narodowego jest podmiotem odpowiedzialnym za nabór i ocenę wniosków w ramach Programu Operacyjnego Infrastruktura i Środowisko. W ramach osi priorytetowej VIII ochrona dziedzictwa kulturowego i rozwój zasobów kultury, działania 8.1 ochrona dziedzictwa kulturowego i rozwój zasobów kultury, finansowane będą inwestycje służące m.in.

${ }^{4}$ Ministerstwo Rozwoju, Szczegółowy opis osi priorytetowych Programu Operacyjnego Polska Cyfrowa na lata 2014-2020, Warszawa, luty 2016, s. 31-37, http://www.polskacyfrowa.gov. pl/media/16275/POPC_SZOOP_02032016.pdf [dostęp: 18.03.2016].

${ }^{5}$ Centrum Projektów Polska Cyfrowa, Zasady kwalifikowania wydatków w ramach II osi priorytetowej Programu Operacyjnego Polska Cyfrowa na lata 2014-2020, Warszawa, 28 sierpnia 2015 r., s. 39-49, http://cppc.gov.pl/wp-content/uploads/Zasady-kwalifikowania-wydatk\%C3\% B3w-2.3-30.11.20151.pdf [dostęp: 19.03.2016].

${ }^{6}$ Ministerstwo Infrastruktury i Rozwoju, Szczegółowy opis osi Priorytetowych Programu Operacyjnego Wiedza Edukacja Rozwój 2014-2020, Warszawa, 22 października 2015 r., s. 162 166, http://www.power.gov.pl/media/10513/SZOOP_POWER_22.pdf [dostęp: 19.03.2016]. 
rozwojowi zasobów kultury. Głównym celem działań podejmowanych w ramach wspomnianej osi i działania jest zwiększenie potencjału turystycznego, rozwój e-kultury, przemysłów kreatywnych i kultury. Beneficjentami wsparcia mogą zostać przede wszystkim szkoły i uczelnie artystyczne prowadzone i nadzorowane przez Ministra Kultury i Dziedzictwa Narodowego oraz szkoły artystyczne prowadzone przez jednostki samorządu terytorialnego. W wypadku państwowych jednostek budżetowych oraz uczelni artystycznych nadzorowanych przez Ministra Kultury i Dziedzictwa Narodowego program przewiduje dofinansowanie projektów do $100 \%$ wydatków kwalifikowalnych pochodzących ze środków europejskich i krajowych. Typy inwestycji podlegających wsparciu unijnemu to renowacja, konserwacja, restauracja obiektów zabytkowych i ich zespołów, przebudowa i rozbudowa obiektów zabytkowych, konserwacja i restauracja zabytków ruchomych uwzględniająca ich ochronę i udostępnienie poprzez proces digitalizacji. W przypadku infrastruktury nie zabytkowej, finansowaniu podlega rozbudowa, przebudowa i remont obiektów na cele działalności kulturalnej, edukacji artystycznej i archiwów. Wsparciu podlega także konserwacja zabytków ruchomych oraz zabytkowych muzealiów, starodruków, księgozbiorów, materiałów bibliotecznych, archiwalnych i zbiorów audiowizualnych, w tym ich ochrona i udostępnienie poprzez proces digitalizacji. Program zakłada jednocześnie, że digitalizacja może być finansowana wyłącznie jako element projektu i nie może być realizowana jako samodzielny projekt. Wykluczeniem w zakresie dofinansowania został objęty zakup wydawnictw do bibliotek, muzealiów, a w przypadku szkół i uczelni artystycznych — działalność dydaktyczna ${ }^{7}$.

Urzędy Marszałkowskie pełniące funkcję administracyjną Instytucji Zarządzających 16 Regionalnymi Programami Operacyjnymi, zapewniły środki na rozwój bibliotek w „cyfryzacyjnych osiach” tych programów. Jednym z głównych celów realizacji omawianych osi, wspierających rozwój cyfrowy regionów, jest digitalizacja i zapewnienie powszechnego dostępu do zasobów nauki i kultury znajdujących się w posiadaniu instytucji szczebla lokalnego i regionalnego. Beneficjenci wsparcia to publiczne uczelnie wyższe, w tym zawodowe szkoły wyższe, które mogą uzyskać dofinansowanie do 85\% kosztów kwalifikowalnych projektu. Typy inwestycji podlegających dofinansowaniu to m.in. budowa i rozbudowa systemów teleinformatycznych służących digitalizacji, prowadzenie prac digitalizacyjnych ${ }^{8}$, tworzenie i rozbudowa repozytoriów cyfrowych, rozwój za-

${ }^{7}$ Ministerstwo Rozwoju, Szczegółowy opis osi priorytetowych Programu Operacyjnego Infrastruktura i Środowisko 2014-2020, Wersja 1.3, Warszawa, 10 lutego 2016 r., s. 173-182, https:// www.pois.gov.pl/media/14655/SzOOP_POIS_1_3_20160210.pdf [dostęp: 19.03.2016].

${ }^{8}$ Zarząd Województwa Dolnośląskiego, Szczegółowy opis osi priorytetowych Regionalnego Programu Operacyjnego Województwa Dolnośląskiego 2014-2020, Wersja 6, Wrocław, 22 lutego 2016 r., s. 85-95, http://rpo.dolnyslask.pl/wp-content/uploads/2016/02/SZOOP_v6_02.2016_ glowny.pdf [dostęp: 20.03.2016]. 
sobów publicznych poprzez tworzenie bibliotek cyfrowych ${ }^{9}$. Wsparciem unijnym zostały objęte także projekty digitalizacyjno-cyfryzacyjne realizowane w ramach Zintegrowanych Inwestycji Terytorialnych, co pozwala na realizację projektów mniejszej skali, a służących rozwojowi e-zasobów naukowych oddziaływujących na cały region ${ }^{10}$.

Przegląd potencjalnych możliwości finansowania projektów bibliotecznych ze względu na poziom dystrybucji środków wskazuje na możliwości wsparcia inwestycji w kapitał ludzki, infrastrukturę techniczną lub zakupu usług, pochodzące w 100\% ze środków europejskich. Jednocześnie istnieje możliwość wsparcia tego typu inwestycji do wysokości $100 \%$ ze środków krajowych — na działalność związaną bezpośrednio lub pośrednio z rozwojem bibliotek. W wypadku środków europejskich pełne finansowanie dotyczy wydatków kwalifikowalnych, określonych we właściwych wytycznych związanych z danym programem operacyjnym szczebla krajowego lub regionalnego. Natomiast w wypadku finansowania krajowego zasady wsparcia określają ustawy i rozporządzenia sektorowe. Trzeba jednak pamiętać, że zarówno w wypadku finansowania europejskiego, jak i krajowego, donator może określić maksymalny poziom dofinansowania, który co do zasady w Regionalnych Programach Operacyjnych wynosi 85\% wydatków kwalifikowalnych. Jednocześnie przeprowadzona analiza dotycząca typów inwestycji finansowanych przez poszczególne instytucje określa podmioty, które przekazują środki na projekty małe, średnie i duże, przy czym wielkość projektu określa maksymalna kwota dofinansowania. Ministerstwo Nauki i Szkolnictwa Wyższego jest donatorem projektów małych związanych z biblioteczną działalnością upowszechniającą naukę i zapewnieniem dostępu do informacji naukowej. Urzędy Marszałkowskie jako podmioty administrujące Regionalnymi Programami Operacyjnymi w imieniu Zarządów Województw finansują projekty średnie związane z digitalizacją, cyfryzacją i udostępnianiem zasobów nauki i kultury na poziomie lokalnym i regionalnym. Natomiast Centrum Projektów Polska Cyfrowa jako Instytucja Pośrednicząca Ministerstwa Rozwoju odpowiada za dystrybucję środków na duże projekty związane z udostępnianiem e-zasobów nauki co najmniej na poziomie krajowym. Ponadto Narodowe Centrum Badań i Rozwoju, także jako Instytucja Pośrednicząca Ministerstwa Rozwoju, pełni funkcję donatora dużych projektów, które kierowane są bezpośrednio do uczelni wyższych, w tym do bibliotek na-

${ }^{9}$ Zarząd Województwa Warmińsko-Mazurskiego, Szczegółowy opis osi priorytetowej Cyfrowy Region Regionalnego Programu Operacyjnego Województwa Warmińsko-Mazurskiego na lata 2014-2020, Olsztyn, 11 grudnia 2015 r., s. 10-23, http://rpo.warmia.mazury.pl/plik/206/szczegolowy-opis-osi-priorytetowych-regionalnego-programu-operacyjnego-wojewodztwa-warminsko-mazurskiego-na-lata-2014-2020 [dostęp: 21.03.2016].

${ }^{10}$ Zarząd Województwa Lubelskiego, Szczegółowy opis osi priorytetowych Regionalnego Programu Operacyjnego Województwa Lubelskiego na lata 2014-2020, Lublin, 23 lutego 2016 r., s. 43-49, http://rpo.lubelskie.pl/dokument-22-szczegolowy_opis_osi_priorytetowych_rpo.html [dostęp: 22.03.2016]. 
ukowych jako wykonawców projektów związanych z rozwojem e-uczelni, w tym e-repozytoriów, e-nauki i e-szkoleń. Przedstawiony w artykule materiał badawczy jednoznacznie wskazuje na dostępność pozabudżetowych środków finansowych na realizację projektów bibliotecznych, znajdujących się w dyspozycji instytucji szczebla krajowego i regionalnego. Biblioteki naukowe zainteresowane pozyskaniem środków zewnętrznych na rozbudowę usług bibliotecznych i infrastruktury bibliotecznej mają możliwość finansowania przede wszystkim rozwoju szeroko pojętych e-zasobów, które będą stanowiły ich przewagę konkurencyjną na rynku usług bibliotecznych, zarówno w regionie, jak i w kraju, a być może także w Europie i na świecie.

\section{Bibliografia}

Centrum Projektów Polska Cyfrowa, Zasady kwalifikowania wydatków w ramach II osi priorytetowej Programu Operacyjnego Polska Cyfrowa na lata 2014-2020, Warszawa, 28 sierpnia 2015 r., http:// cppc.gov.pl/wp-content/uploads/Zasady-kwalifikowania-wydatk\%C3\%B3w-2.3-30.11.20151. pdf [dostęp: 19.03.2016].

Ministerstwo Infrastruktury i Rozwoju, Szczegółowy opis osi Priorytetowych Programu Operacyjnego Wiedza Edukacja Rozwój 2014-2020, Warszawa, 22 października 2015 r., http://www. power.gov.pl/media/10513/SZOOP_POWER_22.pdf [dostęp: 19.03.2016].

Ministerstwo Nauki i Szkolnictwa Wyższego, rozporządzenie Ministra Nauki i Szkolnictwa Wyższego z dnia 11 września 2015 r. w sprawie szczegółowych kryteriów i trybu przyznawania oraz rozliczania środków finansowych na utrzymanie specjalnego urządzenia badawczego, specjalnego urządzenia badawczego z zakresu infrastruktury informatycznej nauki, zapewnienia dostępu do informacji naukowej, w tym do Wirtualnej Biblioteki Nauki, oraz na pokrycie kosztów restrukturyzacji jednostek naukowych, Dz.U. 2015, poz. 1462.

Ministerstwo Nauki i Szkolnictwa Wyższego, rozporządzenie Ministra Nauki i Szkolnictwa Wyższego z dnia 27 października 2015 r. w sprawie kryteriów i trybu przyznawania oraz rozliczania środków finansowych na działalność upowszechniającą naukę, Dz.U. 2015, poz. 1862.

Ministerstwo Nauki i Szkolnictwa Wyższego, Ustawa o zasadach finansowania nauki z dnia 30 kwietnia 2010 roku, Dz.U. 2015, poz. 249, 1268.

Ministerstwo Rozwoju, Szczegółowy opis osi priorytetowych Programu Operacyjnego Infrastruktura i Środowisko 2014-2020, Wersja 1.3, Warszawa, 10 lutego 2016 r., https://www.pois.gov. pl/media/14655/SzOOP_POIS_1_3_20160210.pdf [dostęp: 19.03.2016].

Ministerstwo Rozwoju, Szczegółowy opis osi priorytetowych Programu Operacyjnego Polska Cyfrowa na lata 2014-2020, Warszawa, luty 2016, http://www.polskacyfrowa.gov.pl/media/16275/POPC_SZOOP_02032016.pdf [dostęp: 18.03.2016].

Zarząd Województwa Dolnośląskiego, Szczegółowy opis osi priorytetowych Regionalnego Programu Operacyjnego Województwa Dolnośląskiego 2014-2020, Wersja 6, Wrocław, 22 lutego 2016 r., http://rpo.dolnyslask.pl/wp-content/uploads/2016/02/SZOOP_v6_02.2016_glowny. pdf [dostęp: 20.03.2016].

Zarząd Województwa Lubelskiego, Szczegółowy opis osi priorytetowych Regionalnego Programu Operacyjnego Województwa Lubelskiego na lata 2014-2020, Lublin, 23 lutego 2016 r., http://rpo.lubelskie.pl/dokument-22-szczegolowy_opis_osi_priorytetowych_rpo.html [dostęp: 22.03.2016]. 
Zarząd Województwa Warmińsko-Mazurskiego, Szczegółowy opis osi priorytetowej Cyfrowy Region Regionalnego Programu Operacyjnego Województwa Warmińsko-Mazurskiego na lata 2014-2020, Olsztyn, 11 grudnia 2015 r., http://rpo.warmia.mazury.pl/plik/206/szczegolowyopis-osi-priorytetowych-regionalnego-programu-operacyjnego-wojewodztwa-warminskomazurskiego-na-lata-2014-2020 [dostęp: 21.03.2016].

\title{
Public universities library projects financed from the national and European funds at the disposal of state-level and regional institutions in Poland
}

\author{
Summary
}

The main objective of this article is to provide an overview of potential financing sources for library projects which can be executed by public universities. The most important authorising officers of the funds for pro-development activities of libraries are state-level and regional institutions represented by the Ministry of Science and Higher Education, the Ministry of Culture and National Heritage, Digital Poland Project Centre, the National Centre for Research and Development and Marshall's Offices. The applied method of analysis and synthesis of the acts, regulations and guidelines within the scope of eligible expenditure and a detailed description of national and regional operational projects has allowed for the types of projects which can be financed form non-university national and European resources to be identified. The national and regional level institutions supporting the activities for the development of libraries are mainly focused on the projects concerned with preservation of the unique library resources of high importance for science or its heritage, developing scientific library resources and making them available in digital form, as well as increasing access to data bases which contain scientific information, including Virtual Library of Science. The above mentioned institutions finance or co-finance both the building and the expansion of interoperational scientific digital repositories of regional or national scope, which are user-oriented and co-finance the activities for the improvement of skills in managing information and using professional data bases in educational process. The variety of project types which are subject to external financing makes it possible to execute projects which are in accordance with current strategies for the development of libraries, expressing their current and future plans. The research conducted has shown current availability of funds for the activities for development of scientific libraries on the level of both state and regional institutions. The availability of these funds by means of competition enables the execution of innovative projects, the main purpose of which should be to achieve competitive advantage of specific academic centres on the market of library services in Poland. The research has also confirmed the possibility of obtaining funding form the European or national funds up to $100 \%$ of eligible expenditure of the projects concerned first of all with the development of e-science. It is particularly important in the situation when university budgets cannot ensure financing for all the expenditure connected with pro-development needs of their libraries.

KEYWORDS: external financing sources of the library projects, national funds for the development of libraries, European funds for the development of libraries, pro-development activities of libraries. 